\title{
Comparative study of hydrogen and methane production in the human colon using caecal and faecal homogenates
}

\author{
B Flourié, F Etanchaud, C Florent, P Pellier, Y Bouhnik, J-C Rambaud
}

\begin{abstract}
Rates of hydrogen and methane production were compared in caecal and faecal homogenates in six methane producers. Faecal homogenates produced hydrogen and methane in the absence of and after the addition of lactulose, whereas caecal homogenates produced hydrogen but little methane.
\end{abstract}

Hydrogen $\left(\mathrm{H}_{2}\right)$ and methane $\left(\mathrm{CH}_{4}\right)$ are produced during anaerobic bacterial activity in the human large intestine. Methane is absorbed in portal blood and excreted in breath, and pulmonary $\mathrm{CH}_{4}$ excretion can be used as a simple indicator of $\mathrm{CH}_{4}$ production in the colon.' In general, the population can be divided into two groups on the basis of $\mathrm{CH}_{4}$ excretion - producers and nonproducers of $\mathrm{CH}_{4}{ }^{1}$

In contrast to $\mathrm{H}_{2}$ production, which rapidly fluctuates depending upon the availability of fermentable substrates, $\mathrm{CH}_{4}$ excretion remains relatively constant throughout the day and is not influenced by meals. ${ }^{23}$ Similarly, ingestion of small doses $(10 \mathrm{~g})$ of lactulose, a non-absorbable disaccharide, does not increase breath $\mathrm{CH}_{4}$ excretion. ${ }^{13}$ Larger amounts (20-33 g) of lactulose, however, can cause an appreciable increase in breath $\mathrm{CH}_{4}$ excretion in $\mathrm{CH}_{4}$ producers $^{46}$ - subjects harbouring a sufficient count of methanogenic bacteria, mainly Methanobrevibacter smithii, which uses $\mathrm{H}_{2}$ to reduce $\mathrm{CO}_{2}$ to $\mathrm{CH}_{4}{ }^{7}$ Methanogenic bacteria are strict anaerobes whose growth is favoured by a high $\mathrm{pH}$ and low dilution rates. ${ }^{89}$ These environmental conditions probably exist in the distal but not in the proximal part of the human large intestine. ${ }^{81011}$ Moreover, during experiments aimed at determining the site of colonic $\mathrm{CH}_{4}$ production, Bond $e t a l^{\prime}$ incidentally found that in one subject $\mathrm{CH}_{4}$ production induced by in situ lactose infusion was occurring mainly distal to the colonic splenic flexure.

It was stated by Grimble in a recent issue of Gut, ${ }^{12}$ that these data suggest that $\mathrm{H}_{2}$ and $\mathrm{CH}_{4}$ production may be separated by anatomy in the human large intestine and this prompted us to compare the rates of $\mathrm{H}_{2}$ and $\mathrm{CH}_{4}$ production from lactulose in human caecal and faecal samples.

\section{Methods \\ SUBJECTS}

Studies were carried out on six healthy male volunteers (aged 22-45 years) who were $\mathrm{CH}_{4}$ producers (defined as producing at least one part per million $(\mathrm{ppm}=\mu \mathrm{l} / \mathrm{l})$ of $\mathrm{CH}_{4}$ above room air concentration). ${ }^{\prime}$

\section{CAECAL AND FAECAL SAMPLING}

Caecal content was sampled in fasting subjects after intestinal intubation as described previously. ${ }^{13}$ Subjects were intubated with a double lumen tube led by a mercury bag that could be inflated with air to accelerate progression of the tube. When the bag reached the caecum, which was confirmed fluoroscopically, progression of the tube was stopped by deflating the bag. One lumen sealed with a three way stopcock was used to sample caecal content in a $50 \mathrm{ml}$ sterile syringe after flushing the tube with $10 \mathrm{ml}$ ultra-high purity nitrogen.

On the day elected for tube placement, stools were collected from each subject in a plastic bag containing an Anaerocult A (Merck, Darmstadt, Germany).

\section{IN VITRO INCUBATION AND ANALYSIS}

Caecal and faecal samples were processed immediately. Some $10 \mathrm{~g}$ were homogenised in $60 \mathrm{ml}$ of $0.1 \mathrm{M}$ anaerobic phosphate buffered saline (pH 7). ${ }^{14}$ Two $4 \mathrm{ml}$ aliquots of caecal and faecal samples were then transferred to $50 \mathrm{ml}$ sterile syringes. To one syringe each of treated caecal and faecal samples one $\mathrm{ml}$ of $1.25 \mathrm{~g} / 100 \mathrm{ml}$ solution of pure lactulose (Serva, Heidelberg, Germany) in $154 \mathrm{mM} \mathrm{NaCl}$ was added (experimental incubates), and the $\mathrm{pH}$ was measured with a pH meter (Radiometer, Copenhagen, Denmark). Then one $\mathrm{ml}$ of $154 \mathrm{mM} \mathrm{NaCl}$ was added to the other two syringes (control incubates). The contents of the syringes were mixed by shaking, flushed with $45 \mathrm{ml}$ ultra-high purity nitrogen, and incubated at $37^{\circ} \mathrm{C}$ in a shaking water bath. Delays between all procedures were made as short as possible, and the total duration of handling time was about 15 minutes. After one hour of incubation the gas was recovered from both experimental and control incubates by displacement into another syringe that was equilibrated to room temperature before measurement of $\mathrm{H}_{2}$ and $\mathrm{CH}_{4}$. The syringes were immersed in water at $100^{\circ} \mathrm{C}$ for five minutes, the final $\mathrm{pH}$ was determined, and the amounts of lactulose as fructose were measured by an enzymatic method (Boehringer, Mannheim, Germany). The $\mathrm{H}_{2}$ and $\mathrm{CH}_{4}$ concentrations were multiplied by the volume of gas in the syringes and expressed as $\mu \mathrm{l}$. In the caecal and faecal incubates with lactulose, the volumes of $\mathrm{H}_{2}$ and $\mathrm{CH}_{4}$ were recorded as the changes in $\mu \mathrm{l}$ minus control values. The quantity of lactulose 
that disappeared after one hour of incubation was calculated by subtracting the postincubation value from the added amount of lactulose. Final results were expressed as $\mu \mathrm{l} \mathrm{H}_{2}$ and $\mathrm{CH}_{4}$ per $\mathrm{mg}$ lactulose consumed.

Statistical analysis for significance was performed using Wilcoxon's signed rank test. Data are expressed as mean (SEM).

\section{Results}

In control incubates, the $\mathrm{H}_{2}$ released by faecal homogenates tended to be lower than in caecal homogenates $(0.717(0.446) v 3.560(1.706) \mu \mathrm{l})$. Methane production occurred almost exclusively in faecal incubates at a rate significantly higher than in caecal homogenates $(5.658(1.858) v$ $0.052(0.008) \mu \mathrm{l}, \mathrm{p}<0.05)$. The initial $\mathrm{pH}(6.6$ $v 7 \cdot 2)$ and the final $\mathrm{pH}(6.7 v 7.0)$ did not vary significantly in caecal and faecal control incubates.

The percentage of lactulose consumed during the one hour incubation period was not significantly different in caecal and faecal homogenates $(80.5(5.2) v 97.5(1.5) \%)$. The $\mathrm{H}_{2}$ liberated by faecal homogenates from lactulose tended to be higher than in caecal homogenates. Methane production occurred almost exclusively in faecal incubates at a rate significantly higher than in caecal homogenates $(p<0.05)$ (Table). The initial $\mathrm{pH}(6.6 v 7.2)$ and the final $\mathrm{pH}(5.9 v 6.0)$ were not significantly different in caecal and faecal incubates.

\section{Discussion}

Although lactulose was extensively degraded in both caecal and faecal homogenates $\mathrm{CH}_{4}$ production occurred only in faecal homogenates. The same result was obtained in control incubates. The extent to which the final $\mathrm{pH}$ of the incubates with lactulose changed did not explain the difference in $\mathrm{CH}_{4}$ production between caecal and faecal homogenates. This finding seems to contrast with that of Perman and Modler, ${ }^{15}$ who concluded that $\mathrm{CH}_{4}$ production is sharply $\mathrm{pH}$ dependent. In their incubation experiments, in which $\mathrm{CH}_{4}$ formation was inhibited, however, the $\mathrm{pH}$ of faecal incubates declined to $4 \cdot 0$, whereas it averaged 6.0 in our experimental conditions. In any case, the important point is that the $\mathrm{pH}$ of caecal incubates was not significantly lower than that of the faecal ones.

We did not measure other fermentation products, such as organic acids and total viable anaerobic and methanogenic bacterial concentrations in the faecal and caecal samples. Nevertheless, our results confirm data from an in vitro model mimicking the human colon ${ }^{8}$ and provide further evidence that methanogenesis and probably the growth of methanogenic bacteria are taking place distal to the right part of the large intestine where suitable environmental conditions would be present. This could explain why large oral loads of lactulose able to induce
Hydrogen and methane production ( $\mu \mathrm{l} / \mathrm{mg}$ lactulose consumed) by caecal and faecal homogenates from six $\mathrm{CH}_{4}$ producers after addition of lactulose (mean (SEM))

\begin{tabular}{lll}
\hline & Hydrogen & Methane \\
\hline Caecal homogenates & $0.892(0.457)$ & $0.002(0.001)^{\star}$ \\
Faecal homogenates & $1.206(0.452)$ & $2.607(0.834) \dagger$
\end{tabular}

$\star v+\mathrm{p}<0 \cdot 05$

diarrhoea with the presence of sugars in stools ${ }^{16}$ increase $\mathrm{CH}_{4}$ excretion in $\mathrm{CH}_{4}$ producers ${ }^{+6}$ when a part of this sugar reaches the distal colon, whereas small doses of lactulose, which are completely degraded in the right colon, ${ }^{13}$ do not support $\mathrm{CH}_{4}$ production. A few days ${ }^{2-5}$ are required to observe a sustained increase of $\mathrm{CH}_{4}$ excretion in $\mathrm{CH}_{4}$ producers consuming diets rich in xylan or pectin, ${ }^{17}$ which can escape fermentation in the right colon and reach the distal colon. As the colonic transit time of dietary fibres is slow, it is not surprising that these substrates do not increase $\mathrm{CH}_{4}$ excretion a short time after their ingestion, and this probably explains why breath $\mathrm{CH}_{4}$ excretion is not influenced by meals, unlike $\mathrm{H}_{2}$ which is produced when fermentable substrates from meals are delivered to the right colon.

1 Bond JH, Engel RR, Levitt MD. Factors influencing pulmonary methane excretion in man. $\mathcal{F}$ Exp Med 1971; 133 572-88.

2 Calloway DH, Murphy EL. The use of expired air to measure intestinal gas formation. Ann N Y Acad Sci 1968; 150: 82-95.

3 Tadesse K, Smith D, Eastwood MA. Breath hydrogen $\left(\mathrm{H}_{2}\right)$ and methane $\left(\mathrm{CH}_{4}\right)$ excretion patterns in normal man and in clinical practice. Q $\mathcal{F}$ Exp Physiol 1980; 65: 85-97.

4 Beaven J, Bjorneklett A, Jenssen E, Blomhoff JP, Screde S Pulmonary hydrogen and methane and plasma ammonia after the administration of lactulose or sorbitol. Scand after the administration of lactu

5 Bjorneklett A, Jenssen E. Relationships between hydrogen $\left(\mathrm{H}_{2}\right)$ and methane $\left(\mathrm{CH}_{4}\right)$ production in man. Scand $\mathcal{F}$ Gastroenterol 1982; 17: 985-92.

6 Pitt P, De Bruijn KM, Beeching MF, Goldberg E, Blendis LM. Studies on breath methane: the effect of ethnic origins and lactulose. Gut 1980; 21 : 951-9.

7 Weaver GA, Krause JA, Miller TL, Wolin MJ. Incidence of methanogenic bacteria in a sigmoidoscopy population: an association of methanogenic bacteria and diverticulosis. $G u$ 1986; 27: 698-704.

8 Gibson GR, Cummings JH, MacFarlane GT. Use of a threestage continuous culture system to study the effect of mucin on dissimilatory sulfate reduction and methanogenesis by mixed populations of human gut bacteria. Appl Environ Mixed populations of humal

9 Jones WJ, Nagle DP, Whitman WB. Methanogens and the diversity of Archaebacteria. Microbiol Rev 1987; 51: 135-77.

10 Bown RL, Gibson JA, Sladen GE, Hicks B, Dawson AM Effects of lactulose and other laxatives on ileal and colonic $\mathrm{pH}$ as measured by a radiotelemetry device. Gut $1974 ; 15$ 999-1004.

11 Evans DF, Pye G, Bramley R, Clark AG, Dyson TJ, Hard castle JD. Measurement of gastrointestinal $\mathrm{pH}$ profiles in normal ambulant human subjects. Gut 1988; 29: 1035-41.

12 Grimble G. Fibre, fermentation, flora, and flatus. Gut 1989 30: 6-13

13 Florent C, Flourié B, Leblond A, Rautureau M, Bernier JJ, Rambaud JC. Influence of chronic lactulose ingestion on the colonic metabolism of lactulose in man (an in vivo study). f Clin Invest 1985; 75: 608-13.

14 Flourié B, Florent C, Etanchaud F, Evard D, Franchisseur C, Rambaud JC. Starch absorption by healthy man evaluated Rambaud JC. Starch absorption by healthy man evaluated
by lactulose hydrogen breath test. Am $\mathcal{f}$ Clin Nutr $1988 ; 47$ : by lactul.

15 Perman JA, Modler S. Glycoproteins as substrates for production of hydrogen and methane by colonic bacterial flora. Gastroenterology 1982; 83: 388-93.

16 Saunders DR, Wiggins HS. Conservation of mannitol, lactulose, and raffinose by the human colon. Am $\mathcal{F}$ Physiol 1981 241: G397-G402.

17 Marthinsen D, Fleming SE. Excretion of breath and flatus gases by humans consuming high-fiber diets. $\mathcal{F}$ Nutr 1982 112: 1133-43. 